\title{
Human-to-Human Transmission of Monkeypox Virus, United Kingdom, October 2018
}

Aisling Vaughan, ${ }^{1}$ Emma Aarons, John Astbury, Tim Brooks, Meera Chand, Peter Flegg, Angela Hardman, Nick Harper, Richard Jarvis, Sharon Mawdsley, Mark McGivern, Dilys Morgan, Gwyn Morris, Grainne Nixon, Catherine O'Connor, Ruth Palmer, Nick Phin, D. Ashley Price, Katherine Russell, Bengu Said, Matthias L. Schmid, Roberto Vivancos, Amanda Walsh, William Welfare, Jennifer Wilburn, Jake Dunning

In September 2018, monkeypox virus was transmitted from a patient to a healthcare worker in the United Kingdom. Transmission was probably through contact with contaminated bedding. Infection control precautions for contacts (vaccination, daily monitoring, staying home from work) were implemented. Of 134 potential contacts, 4 became ill; all patients survived.

$\mathrm{M}$ onkeypox is a reemerging zoonosis caused by Monkeypox virus (MPXV), a member of the genus Orthopoxvirus. MPXV is related to Variola virus, the causative agent of smallpox. Although infections with these 2 viruses share many clinical features, monkeypox is generally less severe than smallpox (1). Among unvaccinated persons, the monkeypox case-fatality rate can be up to $10 \%$, although casefatality rates are lower for infection with the West African than the Central African clade of MPXV (2). In recent years, the number of cases and geographic spread of monkeypox have been increasing, possibly because of waning immunity to smallpox (3-5). Before 2018, the only human cases of monkeypox outside Africa occurred in the United States in 2003; that outbreak was associated with rodents imported

Author affiliations: Public Health England, London, UK

(A. Vaughan, E. Aarons, J. Astbury, T. Brooks, M. Chand,

A. Hardman, R. Jarvis, M. McGivern, D. Morgan. G. Morris,

G. Nixon, C. O'Connor, N. Phin, K. Russell, B. Said, R. Vivancos,

A. Walsh, W. Welfare, J. Wilburn, J. Dunning); NIHR Health

Protection Research Unit in Emerging and Zoonotic Infections,

London (A. Vaughan, T. Brooks, D. Morgan, R. Vivancos,

J. Dunning); Blackpool Teaching Hospitals NHS Foundation Trust,

Blackpool, UK (P. Flegg, N. Harper, S. Mawdsley, R. Palmer);

The Newcastle Upon Tyne Hospitals NHS Foundation Trust,

Newcastle Upon Tyne, UK (D.A. Price, M.L. Schmid)

DOI: https://doi.org/10.3201/eid2604.191164 from Ghana, and human-to-human transmission did not occur (6).

In September 2018, Public Health England (PHE) was notified of 2 unrelated cases of monkeypox affecting travelers who had recently returned from Nigeria (7). We describe transmission of monkeypox virus from the second of these cases to a healthcare worker $(\mathrm{HCW})$ and the public health measures implemented to prevent further cases.

\section{The Cases}

On September 6, 2018, a man with a maculopapular rash, fever, lymphadenopathy, and a 1-week history of feeling generally unwell (patient 2) sought care at a hospital in England (7). He was admitted to a singleoccupancy room in the acute medical unit. The staff attending the patient wore standard personal protective equipment (PPE), consisting of disposable aprons and gloves. Because a travel-associated infection was considered possible, patient 2 was transferred to an isolation room on September 7, 2018.

Three days later, a clinical diagnosis of suspected monkeypox was made, and infection prevention and control precautions for a high-consequence infectious disease (HCID) were implemented (e.g., enhanced PPE consisting of disposable gown, disposable gloves, filtering facepiece 3 respirator, and face shield or goggles). The patient was transferred to an Airborne HCID Treatment Centre, and monkeypox was confirmed by laboratory testing at PHE (7).

Although the risk to the public was considered to be very low, a precautionary approach was adopted. Possible hospital and community contacts of patient 2 were identified and assessed for risk (Table).

${ }^{1}$ Current affiliation: London School of Hygiene and Tropical Medicine, London, UK. 
Because smallpox vaccines provide some cross-protection against monkeypox $(8,9)$, a single dose of the third-generation smallpox vaccine, Imvanex (modified vaccinia Ankara; Bavarian Nordic, http:/ / www. bavarian-nordic.com), was offered as postexposure prophylaxis (an off-label indication) to contacts at intermediate and high risk. The target vaccination window for these contacts was within 4 days of exposure, up to a maximum of 14 days from exposure. In addition, preexposure prophylaxis with Imvanex (single dose) was offered to HCID staff involved in the care of confirmed case-patients.

For $3 \mathrm{HCWs}$ who had been assessed for risk, including patient 3 (a healthcare assistant), the same single-exposure risk was identified: $\geq 1$ episode of close contact with the bedding and clothing of patient

Table. Public Health England risk assessment and public health recommendations for persons potentially exposed to 2 patients with monkeypox, United Kingdom, 2018*

\begin{tabular}{|c|c|c|c|c|c|}
\hline Risk group & Description & $\begin{array}{l}\text { Public health } \\
\text { surveillance }\end{array}$ & $\begin{array}{l}\text { Postexposure } \\
\text { vaccination with } \\
\text { Imvanex }\end{array}$ & $\begin{array}{l}\text { No. persons } \\
\text { in risk group }\end{array}$ & $\begin{array}{l}\text { No. }(\%) \text { persons in } \\
\text { risk group who } \\
\text { received postexposure } \\
\text { vaccination† }\end{array}$ \\
\hline No risk & $\begin{array}{l}\text { No known contact (direct or indirect) with a } \\
\text { symptomatic monkeypox case-patientł } \\
\text { OR } \\
\text { Laboratory staff handling specimens from a } \\
\text { monkeypox case-patient, in a laboratory } \\
\text { conforming to UK laboratory standards } \S\end{array}$ & None & $\begin{array}{c}\text { Not } \\
\text { recommended }\end{array}$ & $\begin{array}{c}\text { Not } \\
\text { applicable }\end{array}$ & 0 \\
\hline Low & $\begin{array}{c}\text { HCW involved in care of monkeypox case- } \\
\text { patient while wearing appropriate PPE (with } \\
\text { no known breaches) for all contact episodes } \\
\text { OR } \\
\text { HCW involved in care of monkeypox case- } \\
\text { patient while not wearing appropriate PPE for } \\
\text { all contact episodes but not within } 1 \mathrm{~m} \text { of } \\
\text { case-patient and with no direct contact with } \\
\text { body fluids or potentially infectious material } \\
\text { OR } \\
\text { Community contact not within } 1 \mathrm{~m} \\
\text { of case-patient }\end{array}$ & Passiveף & $\begin{array}{c}\text { Not } \\
\text { recommended }\end{array}$ & 158 & 0 \\
\hline Intermediate & $\begin{array}{l}\text { Intact skin-only contact with a symptomatic } \\
\text { (with rash) monkeypox case-patient, their } \\
\text { body fluids, or potentially infectious material\# } \\
\text { or contaminated fomite } \\
\text { OR } \\
\text { No direct contact but within } 1 \mathrm{~m} \text { of } \\
\text { symptomatic monkeypox case-patient without } \\
\text { wearing appropriate PPE (including } \\
\text { disposable FFP3 respirator or equivalent) }\end{array}$ & Active\# & $\begin{array}{l}\text { Vaccination } \\
\text { may be } \\
\text { considered }\end{array}$ & 125 & $84(67)$ \\
\hline High & $\begin{array}{l}\text { Direct exposure of broken skin or mucous } \\
\text { membranes to monkeypox symptomatic case- } \\
\text { patient, patient's body fluids, or potentially } \\
\text { infectious material }{ }^{* *} \text { (including clothing or } \\
\text { bedding) without wearing appropriate PPE } \\
\text { (including disposable FFP3 respiratory or } \\
\text { equivalent). Exposure includes inhalation of } \\
\text { respiratory droplets or material from scabs } \\
\text { from cleaning rooms where a monkeypox } \\
\text { case-patient has stayed, mucosal exposure } \\
\text { to splashes, penetrating injury from used } \\
\text { sharp device or through contaminated } \\
\text { gloves or clothing }\end{array}$ & Active\# & $\begin{array}{l}\text { Vaccination } \\
\text { recommended }\end{array}$ & 5 & $5(100)$ \\
\hline \multicolumn{6}{|c|}{$\begin{array}{l}\text { gloves or clothıng } \\
\text { *Imvanex (modified vaccinia Ankara, Bavarian Nordic, http://www.bavarian-nordic.com) was approved by the European Medicines Agency in July } 2013 \text { for } \\
\text { active immunization against smallpox in adults. Jynneos (modified vaccinia Ankara; Bavarian Nordic) was approved by the US Food and Drug } \\
\text { Administration in September } 2019 \text { for the prevention of smallpox and monkeypox disease in adults } \geq 18 \text { y of age determined to be at high risk for smallpox } \\
\text { or monkeypox infection. FFP3, filtering facepiece 3; HCW, healthcare worker; PHE, Public Health England; PPE, personal protective equipment. } \\
\text { †For patients } 2 \text { and } 3 \text { combined. } \\
\text { †Case-patients are considered potentially infectious } 24 \mathrm{~h} \text { before the onset of rash. } \\
\text { §See http://www.hse.gov.uk/pubns/books/clinical-laboratories.htm. } \\
\text { TA person requiring passive surveillance is given information about monkeypox and what to do if illness develops. } \\
\text { \#A person requiring active surveillance is given information about monkeypox and instructed to report health status daily to PHE, regardless of symptoms, } \\
\text { for } 21 \mathrm{~d} \text { from the date of most recent exposure, and to report any illness immediately. In addition, HCWs with high-risk exposures are to be excluded from } \\
\text { work for } 21 \mathrm{~d} \text { after the most recent exposure (note this recommendation was introduced after diagnosis of the third case-patient). }\end{array}$} \\
\hline
\end{tabular}


2 before monkeypox was diagnosed. No breaches of standard PPE were identified. All 3 staff members were classified as high-risk contacts and were placed under active surveillance and offered postexposure vaccination. Patient 3 was vaccinated against smallpox on September 14, which was 5 days after the most recent exposure and possibly 6 or 7 days after the earliest exposure to patient 2. Patient 3 had not previously received smallpox vaccine.

On September 22, while off duty, patient 3 noticed a small number of facial lesions and stayed home for the next 2 days but did not report illness to PHE. On September 24, patient 3 sought care with a general practitioner for headache, sore throat, skin lesions on the chin, earache, and eye pain. Patient 3 then reported the illness to PHE.

The general practitioner discussed the case with PHE and provided images of the skin lesions, which were consistent with monkeypox. Further medical assessment of patient 3 at the local hospital was arranged. After assessment and collection of diagnostic specimens, patient 3 remained isolated at home. On September 25, monkeypox was confirmed by PCR testing of multiple sample types, and patient 3 was admitted to an Airborne HCID Treatment Centre.

A total of 134 possible contacts of patient 3 were identified, including staff and patients on the ward where patient 3 worked, family and community contacts, and staff and patients at the general practitioner's office where patient 3 had sought care. Patient 3 had not been working when rash was present; however, as a precaution, all those who had had contact with patient 3 during the 24 hours before onset of the rash (i.e., on September 21) were monitored. Postexposure vaccination was offered to eligible contacts at intermediate and high risk (Table). As an extra precautionary measure, active monitoring, with daily reporting of presence or absence of signs or symptoms, was extended to all outstanding contacts of patient 2 and all new contacts of patient 3 . In addition, HCW contacts at high risk were instructed not to attend work for 21 days from the most recent exposure (the incubation period for monkeypox is 5-21 days) (10).

A total of 4 contacts of patient 3 became ill within the incubation period and required medical assessment. No further cases of monkeypox were identified in relation to this incident and, after clinical improvement, patient 3 was discharged on October 29, 2018.

\section{Conclusions}

Cases of human monkeypox outside Africa are rare; in the United Kingdom, the likelihood of travelassociated monkeypox cases is low (10-12). To our knowledge, human-to-human transmission of monkeypox outside Africa has not been reported, and human-to-human transmission of the West African clade has been reported for Nigeria only (4). Such transmission may occur through close contact with skin lesions of an infected person, via fomites, or by exposure to large respiratory droplets during faceto-face contact (1). The transmission reported here occurred from a patient with a travel-associated case to an HCW. The only exposure risk identified during assessment of patient 3 was the changing of potentially contaminated bedding, when patient 2 had multiple skin lesions but before a diagnosis of monkeypox had been considered. The use of standard PPE may not have afforded sufficient protection against monkeypox, particularly if skin lesion debris containing virus had been disturbed and inhaled when bedsheets were changed.

Although patient 3 received postexposure vaccination before symptom onset, vaccination was $>4$ days after the most recent exposure to patient 2 . The optimal timing for postexposure vaccination with Imvanex remains unknown, and the postexposure window period chosen for this incident was informed, in part, by that used during the US outbreak in 2003 (6). Patient 3 may have been vaccinated too late to prevent monkeypox.

During this incident, the risk to the public was determined to be very low because effective humanto-human transmission requires close contact with an infected person or virus-contaminated materials. Regardless, monkeypox is considered an HCID in England because it meets the UK criteria (13).

Monkeypox cases associated with travel to Nigeria have subsequently been detected in Israel (14) and Singapore (15). Although monkeypox is rare outside disease-endemic countries in Africa, this incident illustrates the need to be aware of monkeypox as a reemerging and travel-associated infection. Clinicians should consider a potential diagnosis of monkeypox early for patients with compatible symptoms and potential exposure risks, including recent travel to a disease-endemic country. In healthcare settings, implementation of appropriate infection prevention and control precautions as soon as monkeypox is suspected will help prevent secondary transmission.

\section{Acknowledgments}

We acknowledge all members of the National Incident Management Team and others involved in the response to this incident. Our thanks go to colleagues at PHE North West Centre, the PHE Rare and Imported Pathogens Laboratory, the PHE Imported Fever Service, PHE Field 
Service, PHE Communications team, NHS England and NHS Improvement, Blackpool Teaching Hospitals NHS Foundation Trust, Newcastle upon Tyne Hospitals NHS Foundation Trust, Royal Free London NHS Foundation Trust, Royal Liverpool and Broadgreen University Hospitals NHS Trust, the Animal and Plant Health Agency, the Department of Health and Social Care, the Department for Environment, Food \& Rural Affairs, Health Protection Scotland, Public Health Agency of Northern Ireland, Public Health Wales, The Advisory Committee for Dangerous Pathogens, the Joint Committee on Vaccination and Immunisation, Lancashire County Council, Blackpool Council, Wyre Council, Fylde and Wyre Clinical Commissioning Group, North West Ambulance Service, Fylde Coast Medical Services, UK Government Decontamination Service, Braemar Response Ltd, Bavarian Nordic A/S, and the Nigeria Centre for Disease Control.

\section{About the Author}

At the time of the incident, Dr. Vaughan was an epidemiologist in the Emerging Infections and Zoonoses Section at PHE and a Research Fellow at the NIHR Health Protection Research Unit in Emerging and Zoonotic Infections. She is now a research fellow in Infectious Disease Epidemiology at the London School of Hygiene and Tropical Medicine. Her primary research interests include emerging infections, field epidemiology, and outbreak investigation.

\section{References}

1. McCollum AM, Damon IK. Human monkeypox. Clin Infect Dis. 2014;58:260-7. https://doi.org/10.1093/cid/cit703

2. Likos AM, Sammons SA, Olson VA, Frace AM, Li Y, Olsen-Rasmussen $\mathrm{M}$, et al. A tale of two clades: monkeypox viruses. J Gen Virol. 2005;86:2661-72. https://doi.org/10.1099/vir.0.81215-0

3. Durski KN, McCollum AM, Nakazawa Y, Petersen BW, Reynolds MG, Briand S, et al. Emergence of monkeypoxWest and Central Africa, 1970-2017. MMWR Morb Mortal Wkly Rep. 2018;67:306-10. https://doi.org/10.15585/ mmwr.mm6710a5

4. Sklenovská N, Van Ranst M. Emergence of monkeypox as the most important orthopoxvirus infection in humans.
Front Public Health. 2018;6:241. https://doi.org/10.3389/ fpubh.2018.00241

5. Yinka-Ogunleye A, Aruna O, Dalhat M, Ogoina D, McCollum A, Disu Y, et al.; CDC Monkeypox Outbreak Team. Outbreak of human monkeypox in Nigeria in 2017-18: a clinical and epidemiological report. Lancet Infect Dis. 2019;19:872-9. https:/ / doi.org/10.1016/ S1473-3099(19)30294-4

6. Centers for Disease Control and Prevention (CDC). Update: multistate outbreak of monkeypox - Illinois, Indiana, Kansas, Missouri, Ohio, and Wisconsin, 2003. MMWR Morb Mortal Wkly Rep. 2003;52:642-6.

7. Vaughan A, Aarons E, Astbury J, Balasegaram S, Beadsworth M, Beck CR, et al. Two cases of monkeypox imported to the United Kingdom, September 2018. Euro Surveill. 2018;23. https://doi.org/10.2807/1560-7917. ES.2018.23.38.1800509

8. Fine PE, Jezek Z, Grab B, Dixon H. The transmission potential of monkeypox virus in human populations. Int J Epidemiol. 1988;17:643-50. https:/ / doi.org/10.1093/ije/17.3.643

9. Rimoin AW, Mulembakani PM, Johnston SC, Lloyd Smith JO, Kisalu NK, Kinkela TL, et al. Major increase in human monkeypox incidence 30 years after smallpox vaccination campaigns cease in the Democratic Republic of Congo. Proc Natl Acad Sci U S A. 2010;107:16262-7. https:/ / doi.org/10.1073/pnas.1005769107

10. World Health Organization. Monkeypox [cited 2019 Jul 23]. http://www.who.int/news-room/fact-sheets/detail/ monkeypox

11. European Centre for Disease Prevention and Control. Rapid risk assessment: monkeypox cases in the UK imported by travellers returning from Nigeria, 2018 [cited 2019 Jul 23]. https:/ /ecdc.europa.eu/en/publications-data/rapid-riskassessment-monkeypox-cases-uk-imported-travellersreturning-nigeria

12. Public Health England. Monkeypox case in England [cited 2019 Jul 25]. https://www.gov.uk/government/news/ monkeypox-case-in-england

13. Public Health England. High consequence infectious diseases (HCID) [cited 2019 Jul 23]. https:/ / www.gov.uk/guidance/ high-consequence-infectious-diseases-hcid

14. Erez N, Achdout H, Milrot E, Schwartz Y, Wiener-Well Y, Paran N, et al. Diagnosis of imported monkeypox, Israel, 2018. Emerg Infect Dis. 2019;25:980-3. https://doi.org/10.3201/eid2505.190076

15. Singapore Ministry of Health. Confirmed imported case of monkeypox in Singapore [cited 2019 Jul 23]. https://www.moh.gov.sg/news-highlights/details/ confirmed-imported-case-of-monkeypox-in-singapore

Address for correspondence: Jake Dunning, Public Health England, National Infection Service, 61 Colindale Ave, London NW9 5EQ, UK; email: jake.dunning@phe.gov.uk 